\title{
An Evaluation of the Trends in Land Values around Institutions of Higher Learning in North Central Nigeria
}

\author{
Nwokenkwo, B.C. ${ }^{1, *}$, Ike, F. ${ }^{2}$ and Eze, M.U. ${ }^{3}$ \\ ${ }^{1}$ Department of Estate Management and Valuation, School of Environmental Studies, The Federal Polytechnic, \\ Bida, Niger State, Nigeria \\ ${ }^{2}$ Department of Geography and Planning, Faculty of Environmental Studies, Abia State University, Uturu, Abia \\ State, Nigeria \\ ${ }^{3}$ Department of Estate Management, Faculty of Environmental Studies, Abia State University, Uturu, Abia \\ State, Nigeria
}

Corresponding Author: *benchinedum@gmail.com

\begin{abstract}
The need to study trends in land values around institutions of higher learning cannot be overemphasized. Numerous studies in Nigeria have investigated the economic and social influence of the siting of institutions of higher learning at the micro, meso and macro levels. However, very few studies have evaluated the extent at which such institution influences local land values. Institutions, to a large extent, exert an element of control on the physical and environmental aspects of their immediate vicinity. Therefore, attention must be in place to evaluate the influence of such control on land values. This study examined the trend in land values using the Mann-Kendall analysis in order to determine monotonic increase, decrease or stability in the land values across six institutions of higher learning for the period between 2004 and 2014. Specifically, the results of this study revealed that land values have either been increasing or remained stable in all institutions. The study finally recommends measures that can be put in place as counter measures for land values across institutions of higher learning.
\end{abstract}

Keywords: Land, Value, Trends, Institutions, Physical Environment

\subsection{Introduction}

Land occupies a unique place in the development process of any society. The supply of usable land is, however, limited (Shaba et al., 2013). The importance of land to man on earth through all ages can hardly be over emphasized. Land provides a platform on which man's activities are predicated (Wildcat et al., 2014). The location of institutions of higher learning has the potential of affecting the price and value of land. Similarly, competitions in the land market (as a determinant for price) are likely to be affected by locational factors. Such trends to a large extent, determines and controls the price of the land in such locations (Ayala et al., 2018). Land is a valuable asset, and is controlled mainly by the level of social economic development, level of competitions, and crime rates (McLaren and Hawe, 2005). The growing demand for land has led to increase in land price; this became heightened with the increase in institution of higher learning in all parts of the nation. Consequently, over the past two to three decades, the land pricing market in Nigeria has experienced an upward trend due to growth and increase in number of Institution of Higher Learning across all parts of the nation.

Considering the current challenges of rapid growth in educational institutions in North Central Nigeria, consistent economic depression and high level of poverty, a study that seeks to improve understanding in the current state price determination system is probably most desirable. Aribigbola (2008) emphasizes that there is an urgent need to create conditions in which all sections of society understand the land market mechanism. 
Most institutions in North Central Nigeria has grown consistently in academic programmes and student numbers since the 1990s when the government at the time was committed to the expansion of higher education as one of the development strategies to enhance education for the necessary economic and social development in Northern Nigeria (Fadare, 2013). From that time, student population, social and developmental amenities have increased in North Central Nigeria by over 33\% (Ladan, 2004). There is no gain saying that the demand for higher education in North Central Nigeria is expanding (considering the contribution of successive administrations in Nigeria) and pushing the student population growth upwards which is factored by the transformation (social and facilities provisions inclusive) of educational institutions. As an example, some Polytechnics were "upgraded", while new universities were also established.

Institutions of higher learning can greatly influence both the physical and environmental aspects of their immediate vicinity; attention must be taken to understand the influence of such changes on land values driven by locational factors (Akbari et al., 2004). By understanding the trends in land values over time, effective retrospective and prospective flux in land values can be better mitigated using policies and counter measures (Cernea and Christopher, 2000). The aim of this paper is to evaluate the trend of land values and in relation to the siting of institution of higher learning from selected institutions in North Central Nigeria.

\subsection{Methodology}

The study area is North Central Nigeria. It consists of the seven states situated geographically in the middle belt region of the country, spanning from the West, around the confluence of the River Niger and the River Benue. The region itself is rich in natural land features, and boasts some of Nigeria's most exciting scenery. The study focused on three states, which are, Niger, Nasarawa and Kogi State (Figure 1).

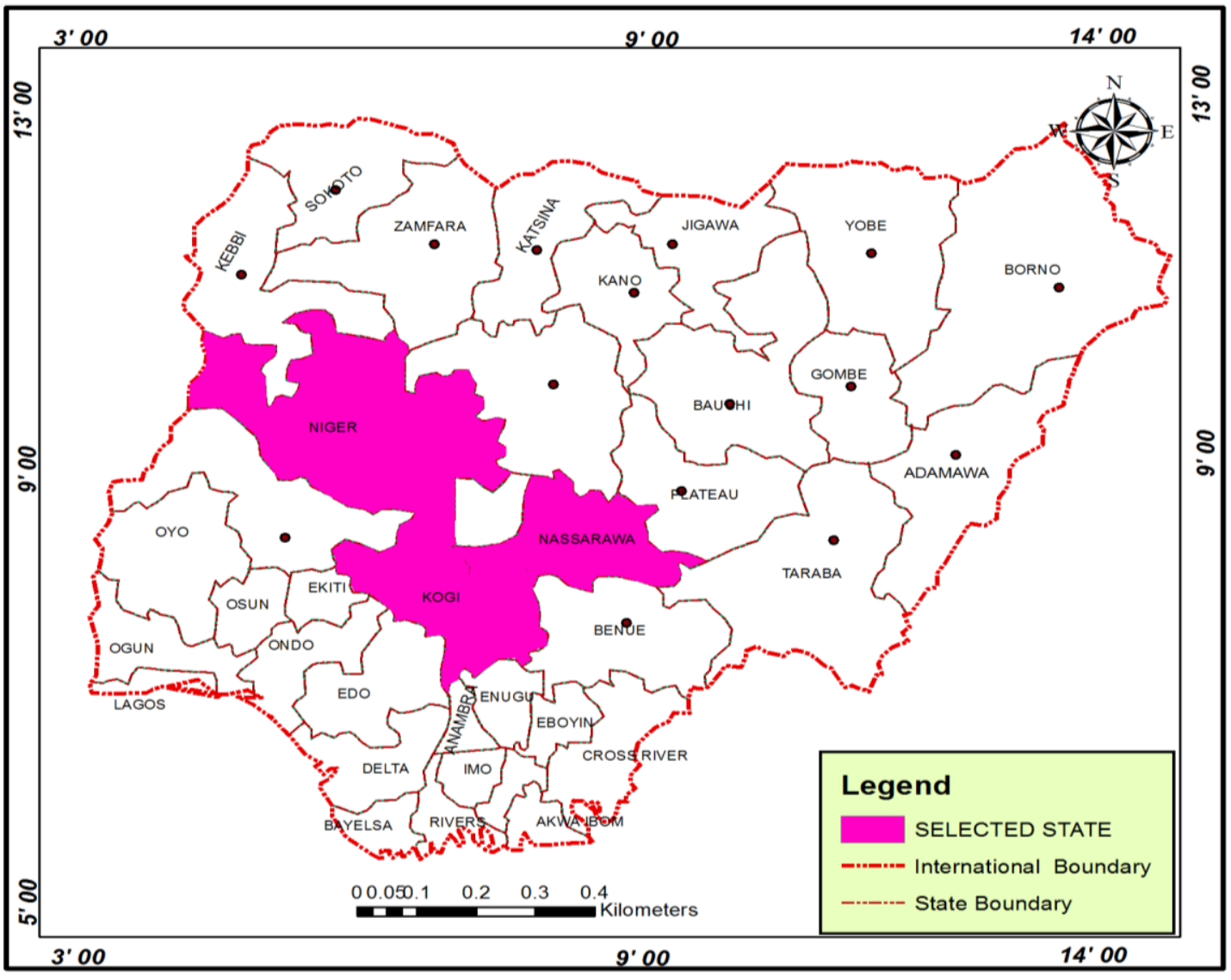

Figure 1: Location of selected states in North Central Nigeria (Source: National Space Research Development Agency, Abuja) 
This paper focuses on the trend of land values across six institutions of higher learning in North Central Nigeria. The six institutions selected are: Nasarawa State University Keffi (NSUK), College of Education Akwanga (COEA), Federal University of Technology Minna (FUTM), Federal College of Education Kontagora (FCOEK), Kogi State University Anyigba (KSUA), and Federal College of Education Okene (FCOEO). The geographical scope of this work covered an area of $6 \mathrm{~km}$ radius around the selected institutions. Further to the $6 \mathrm{~km}$ grid, it should be noted that each of the sample institution were selected based on the premise that the adjoining geographical landscape for land development around the institution were not hindered by any natural geographical factor which could affect plots of land available. The analysis also involved collection of data on the values of land across the sampled institutions. In order to estimate the land values across the sampled institutions, Mann Kendall analysis was used to determine monotonic increase, decrease or stability in land values around the higher educational institutions. The Mann-Kendall trend statistic (S) is dependent on the Confidence Factor (CF) and the Coefficient of Variation (COV).

The trend is said to be decreasing if $Z$ is negative and the computed probability is greater than zero. If $Z$ is positive and the probability value is greater than the level of significance, the trend is said to be increasing. The trend is said to be stable or 'no trend' if the computed probability is less than the level of significance.

The test statistic Kendall $S$ is calculated as:

$$
\begin{gathered}
S=\sum_{j=1}^{n-1} \sum_{j=k+1}^{n} \operatorname{sgn}\left(x_{j}-x_{k}\right) \\
\begin{array}{c}
x \quad \text { data values at times } j \text { and } k \\
n \quad \text { length of the dataset }
\end{array} \\
\left(x_{j}-x_{k}\right)=\left\{\begin{array}{c}
+1 \text { if }\left(x_{j}-x_{k}\right)>0 \\
0 \text { if }\left(x_{j}-x_{k}\right)=0 \\
-1 \text { if }\left(x_{j}-x_{k}\right)<0
\end{array}\right\} \\
\operatorname{Var}=\frac{\operatorname{|n}(n-1)(2 n+5)-\sum t(t-1)(2 t+5) \mid}{18}
\end{gathered}
$$

The Mann-Kendall test has two parameters that are of importance for trend detection. These parameters are the significance level that indicates the test strength and the slope which indicate the direction as well as the magnitude of the trend. The notation $t$ is the extent of any given tie and $\Sigma t$ denotes the summation over all ties. In cases where the size $n>10$, the standard normal value $Z$ is computed by using Equation 4.

$Z=\left\{\begin{array}{c}\frac{s-1}{\sqrt{\operatorname{Var}(s)}} \text { if } s>0 \\ 0 \text { if } s=0 \\ \frac{s+1}{\sqrt{\operatorname{Var}(s)}} \text { if } s<0\end{array}\right\}$

In order to evaluate the trends in land values around each of the Institution, the following operations were carried out before applying the Mann-Kendall Model using Macro Files in SPSS:

a) Raw data on land values were assembled from secondary data records and government archives for the period between 2004 and 2015. A summary of the aggregated data used in this study (2004 - 2014) is presented in Table 1.

b) The raw data on land prices were divided into two groups (see Table 1). The first group contained data on prices of land already sold; the second, contained current prices of available 
land. For the plots that were already sold, the total area of the plot size were aggregated with the cost of the land, thereby producing an average value for a plot size with the buffer zone around each institution for the first and second groups.

c) Finally the Mann-Kendall Model Macro file was applied to determine the trends in land values across the sampled institutions.

Table 1: Summary of Aggregated Data for Land Values Matrices of the Institutions.

\begin{tabular}{|l|l|l|l|l|l|}
\hline $\begin{array}{l}\text { Year/Inst. } \\
\text { 2004-2014 }\end{array}$ & $\begin{array}{l}\text { Cost of Land } \\
\text { Sold N/Plot }\end{array}$ & $\begin{array}{l}\text { Cost of Land } \\
\text { Available N/plot }\end{array}$ & $\begin{array}{l}\text { Aggregation } \\
\text { matrix }\end{array}$ & $\begin{array}{l}\text { Average Land } \\
\text { Value }\end{array}$ & Number of Data Points \\
\hline KSUA & 176,131 & 161,073 & 0.9785 & 218,627 & 131 \\
\hline FCOEO & 98,323 & 81,757 & 0.8007 & 129,129 & 189 \\
\hline NSUK & 234,116 & 293,895 & 0.8129 & 239,630 & 114 \\
\hline COEA & 127,114 & 106,032 & 0.9464 & 150,132 & 123 \\
\hline FUTM & 323,567 & 318,170 & 0.9915 & 360,633 & 145 \\
\hline FCOEK & 116,865 & 130,307 & 0.9974 & 171,135 & 109 \\
\hline
\end{tabular}

\subsection{Results and Discussion}

\subsection{Trend in land values}

Tables 2 and 3 are the Mann-Kendall Trend for land value between 2004 and 2014 around each of the Institution. The analysis was applied to the time series of the price (or value) of the land to understand if between 2004 and 2014 their trends are increasing, decreasing or undefined (no trend).

At Kogi State University, a negative $Z$ value coupled with a high $P$ value for upward trend of 0.65 ( $P$ $<0.05$ ) indicates that price of land around Kogi State University has been increasing.

Table 2: Mann-Kendall Matrices for Land Values

\begin{tabular}{|l|l|l|l|}
\hline $\begin{array}{l}\text { Year/Inst. 2004 } \\
-2014\end{array}$ & $\begin{array}{l}\text { P-values for } \\
\text { Upward trends in } \\
\text { Land Value }\end{array}$ & $\begin{array}{l}\text { P-values for Downward } \\
\text { Trends in Land Value }\end{array}$ & Z values \\
\hline KSUA & 0.41 & 0.43 & 1.65 \\
\hline FCOEO & 0.13 & 0.17 & 0.61 \\
\hline NSUK & 0.41 & 0.61 & -1.44 \\
\hline COEA & 0.41 & 0.37 & 1.21 \\
\hline FUTM & -0.15 & -0.09 & 2.57 \\
\hline FCOEK & -0.43 & -0.35 & 2.16 \\
\hline
\end{tabular}

FCOE Okene also recorded a high $P$ value $0.61(P<0.05)$ showing an upward trend thus having the same result as Kogi State University. At NSUK, a negative $Z$ value coupled with low $P$ value for upwards and downwards trends shows that land prices have not been increased or reduced. At the College of Education Akwanga, the prices of land has been increasing due to the relatively high $P$ value for upwards trend. The Federal University of Technology Minna also recorded an increasing trend in land price for the period between 2004 and 2014. This is as a result of the higher $(0.57, P<$ $0.05)$.

Table 3: Summary of Mann-Kendall Trend for Land Values

\begin{tabular}{|l|l|}
\hline Year 2004-2014 & Land Value \\
\hline KSUA & Increasing \\
\hline FCOEO & Increasing \\
\hline NSUK & No Trend \\
\hline COEA & Increasing \\
\hline FUTM & Increasing \\
\hline FCOEK & Increasing \\
\hline
\end{tabular}

Decreasing $=$ Negative trend in the Value of the land-Kendall trend $(p \leq 0.05)$, Increasing $=$ Positive trend in the value of the land Mann-Kendall trend $(p \leq 0.05)$, No trend $=$ relatively stable trend at $(p \leq 0.05)$

(Source: Results of Analysis)

Table 2 is a summary of the Mann Kendall analysis generated using changes in the price of the land with data generated from land agents and campus data services in each of the institution. In Kogi 
State, between 2004 and 2014 the values of land were increasing at Kogi State University, and Federal College of Education, Okene. For the two institutions sampled in Nasarawa State, land values around NSUK showed no trend for the period between 2004 and 2014, but for the Federal College of Education Akwanga, the value of land was increasing. In Niger state land values around the Federal University of Technology, Minna showed an increasing trend while around the Federal College of Education Kotangora, land values also showed an increasing trend.

\subsection{Conclusion}

This study revealed that there is a significant relationship between land values and location-based factors around Institution of Higher Learning. By implication, the major determinants of land values around higher education institutions may be driven by the siting of such institution. It is also possible that changes in land price were possibly influenced by various factors such as demand for land from buyers, location, surrounding development and situation of the economy. This study finally recommends that before siting or administering land for any growth pole project (e.g. higher educational institution) attention should focus on the need to assign priority thresholds to other environmental factors that could cushion the distance-effects of such projects on land values.

\section{References}

Akbari, N.A., Emadzadeh, M. and Razavi, S.A. (2004). Investigation of Affecting Factors on Housing Price in Mashhad City. The Economic Research, 4(11-12), pp. 57-78. (In Persian).

Aribigbola, A. (2008). Housing Policy Formulation in Developing Countries: Evidences of Programme Implementation from Akure, Ondo State Nigeria. Journal of Human Ecology, 23 (2).

Ayala W., Lenis S. and Liverpool T. (2018). Land markets and migration trends in Tanzania: A qualitative-quantitative analysis. Journal of Development Policy Review, 36(8), pp. 31-56.

Cernea, M. and Christopher M. (eds). (2000). Risks and Reconstruction. Experience of Resettles and Refugees. Wahington: The World Bank

Fadare, S. (2013). Emerging Issue in Urban Planning and Development; Department of Urban and Regional Planning, Faculty of Environmental Science, University of Lagos, Nigeria, 189 - 217

Ladan, M. T. (2004). Status of Environmental Law in Nigeria: Implementation Teaching and Research at a Symposium for Environmental Law Senior Lecturers / Professors from African Universities. Organized by the UNEP Nairobi Kenya

McLaren, L. and Hawe, P. (2005). Ecological Perspectives in Health. Research Journal of Epidemiology \& Community Health, 59, pp. 6-14.

Shaba, H., Mohammed, S.O., Gajere, E.N., Eguaroje, E.O., Ogbole, J.O., Mangut, Y.S., et al. (2013). Spatio - Temporal Analysis of the National Parks in Nigeria Using Geographic Information System. Ife Journal of Science, 15(1).

Wildcat, M.M., MandeeIrlbacher-Fox, S. and Coulthard, G. (2014). Learning from the land: Indigenous land based pedagogy and decolonization. Journal of Decolonization: Indigeneity, Education Society, 3, pp. 16-21. 